\title{
Critical Junctures in Sustainable Social Housing Policy Development in Saudi Arabia: A Review
}

\author{
Khalid Abdullah Mulhim Al Mulhim ${ }^{1,2, *}$, Mohammad Shahidul Hasan Swapan ${ }^{2} \mathbb{E}$ and Shahed Khan ${ }^{2}$ \\ 1 College of Architecture and Planning, Imam Abdulrahman Bin Faisal University, \\ Dammam 34212, Saudi Arabia \\ 2 School of Design and the Built Environment, Curtin University, Bentley 6102, Australia; \\ m.swapan@curtin.edu.au (M.S.H.S.); s.khan@curtin.edu.au (S.K.) \\ * Correspondence: kmulhem@iau.edu.sa or khalid.almulhim@postgrad.curtin.edu.au
}

Citation: Al Mulhim, K.A.M.; Swapan, M.S.H.; Khan, S. Critical Junctures in Sustainable Social Housing Policy Development in Saudi Arabia: A Review.

Sustainability 2022, 14, 2979. https:// doi.org/10.3390/su14052979

Academic Editors: Grazia Napoli and Maria Rosa Trovato

Received: 19 January 2022

Accepted: 22 February 2022

Published: 3 March 2022

Publisher's Note: MDPI stays neutral with regard to jurisdictional claims in published maps and institutional affiliations.

Copyright: (C) 2022 by the authors. Licensee MDPI, Basel, Switzerland. This article is an open access article distributed under the terms and conditions of the Creative Commons Attribution (CC BY) license (https:// creativecommons.org/licenses/by/ $4.0 /)$.

\begin{abstract}
Historicising social housing delivery approach is extensively carried out for Western countries, but studies of social housing policy journey are less focused on developing nations and examining the policy development within resource-abundant Middle Eastern countries is even rarer. Applying a critical juncture approach through the historical institutionalism lens, this paper seeks to understand the evolution of social housing policies within the Saudi Arabian context. An in-depth policy review suggests that the institutional response in this sector has transitioned from a publicwelfare perspective to a more neoliberal vision in recent times. The study also indicates a time-lag in policy development regarding social housing within the urban development process in Saudi Arabia compared to global movement. During the past few years, the government has begun to focus on social housing under the developmental housing program with a commitment to link these strategies to the Saudi Vision 2030. While this is a significant policy-shift in the service delivery approach, such vision could be workable as long as sufficient room is built in for other non-government actors to work within their specific protocols and frameworks as they collaborate to provide affordable and appropriate housing for the neediest groups of the society.
\end{abstract}

Keywords: social housing; critical junctures; housing delivery; public-private partnership; Vision 2030; Saudi Arabia

\section{Introduction}

While two-thirds of the world's population is expected to live in urban areas by 2050, the housing challenge will be critical particularly for low-income urbanites [1,2]. Housing is one of the key determinants of sustainable development, which constitutes the critical focus for the well-being of people. Therefore, sustainable social housing initiatives seek to provide standards that achieve the desired goals for developing communities in the longer term [3]. Social housing reforms focus on housing sustainability and its efficient practice [4]. Furthermore, one significant aspect of social housing is to ensure guaranteed access for the needy, which is their fundamental right [5]. Countries across the globe are conscious that housing is one of the key elements in the formation of cities; it has a significant impact on socio-economic status, politics, security, and other aspects of people's lives [6]. Addressing the poor and neediest groups in the society through social housing also helps to maintain social justice and resist further illegal encroachment of public lands that could contribute to an unsustainable urban landscape (Kellett, Christen [4,7,8]).

Furthermore, according to the United Nations Development Programme [9], urban equity increases social development. In other words, social cohesion is an issue of fundamental importance when building new communities for greater social sustainability [10].

It is noticeable that the most significant and fastest-growing construction and real estate markets are in the developing world; however, despite the vast number of projects, the demand exceeds the supply, which causes a problem for the most vulnerable groups. 
In addition, failure to consider the aspects of sustainability may reduce the quality of housing, which constitutes an extra burden on these groups in the future concerning quality and maintenance. Therefore, focusing on the sustainability of social housing provides tangible social, economic and environmental results for lower-income groups [11]. The past few decades have seen a shift in emphasis towards developing a sustainable social housing policy to deliver adequate and affordable housing for the urban poor in many developing countries such as the Kingdom of Saudi Arabia (KSA), which is experiencing massive urbanisation and infrastructural development [12]. Processes and mechanisms of social housing delivery introduced in response to the increasing urbanisation and the accompanying housing needs of marginal groups, correlate to political and historical events. From the theoretical perspective of historical institutionalism, such events are termed as critical junctures in the policy development process [13]. Social housing is a widely practised housing model to accommodate the most vulnerable groups in the society [14]. The adoption of social housing indicates the nature of governmental support directed to low-income families to avail appropriate accommodation [15]. Social housing offers a more sustainable perspective of housing, denoted by co-produced housing options delivered by various parties including governments, non-governmental organisations (NGOs) or housing associations, aimed at providing adequate housing to marginalised groups [16]. In each national context, the nature of the model is significantly determined by the character of the vulnerable groups, the actors involved in housing delivery, and the government's political and policy agenda.

There is no doubt that housing policies have undergone manyfold changes historically, based on political decisions and urban growth milestones. The concept of social housing is rooted in developments in the pre-industrial revolution era around meeting housing needs of the working-class population encountering a shortage of sufficient and affordable housing supply [17]. The movement further crystallised from a philanthropic perspective and industrial interests addressing the influx of the working-class and rapid urban growth $[18,19]$.

The social housing policy emerged in the USA to protect workers' rights through public housing programmes [20,21]; however, the policy overlooked the extremely poor groups until the new housing law was issued in 1937 [22,23]. This law provides the mechanism of public funding for low-cost housing in several US cities with a high population density, represented in some projects owned and managed by the public housing authorities [24]. Noteworthy, the USA provides housing in a variety of interrelated ways.

In England, the basis of development was based on several considerations beginning with the establishment of lease controls introduced back in 1916. These controls transformed the English community from a rental dependent society to estate ownership. The middle class benefited from these controls more than the low-income groups [25]. As for social housing in England, it began as a temporary solution resulting from capitalism in order to meet the bottom line of the working class; however, this theory did not resonate with some opponents of the idea. The opponents indicated that the role of the social rental sector declined due to several economic and social factors $[17,26]$.

Additionally, many countries focused on supporting housing policies as a luxury during the post-WWII era, while others focused on supporting the disadvantaged's fundamental rights [14]. Fundamental changes in social housing delivery can be traced back to the 1970s when the support shifted from purchasing and repairing homes to providing subsidised rental help for the urban poor [27]. In the 1980s, social housing provision tended to decline in some European countries, as they gradually encouraged a freer market to provide decent housing for those with limited affordability $[19,28]$.

Since the 1990s, several ideas have emerged (such as co-production, co-housing and affordable housing) based on a neo-liberal ideology/partnership, offering increasing opportunities for communities to contribute to the decision-making processes [29]. Many countries recently have witnessed transformations and trends towards neoliberalism and a reduced dependence on centralisation. The neoliberal philosophy relies on the transfer 
of powers partially or entirely to local governments or independent and private sectors. Additionally, the application of neoliberal experiences is not limited to developed countries, as it is also practised in developing countries [30,31]. The central government or welfare state is seen as the leading provider of services in this sector. It is considered that centralised systems are more comprehensive and independent in their decisions, making them more inclined to the welfare state [32]. On the contrary, the decentralised system relies on independence in decision-making and financial support because it depends on its revenues. In turn, this encourages competitiveness, increases efficiency, and provides flexibility for decision-makers to set their priorities [33].

More recently, the Sustainable Development Goals (SDGs 11) have focussed upon eradicating housing inequality and stress through affordable housing for the urban poor $[34,35]$. Policy changes at a certain point in time can constitute critical strategies for achieving desired goals. Meanwhile shifts in policy directions are often affected by a formal process through institutional reforms and binding guidelines, whereas informal and less structured processes, including contemporary political vision and market forces, equally contribute to the transformation of policy landscape and operational mechanisms [36]. In a wider perspective, policies can be seen as traveling between countries through the conduits of technical and financial support where economic status and a power-imbalance interplay on the policy outcomes [37].

\subsection{Saudi Context and the Research Agenda}

The Saudi Arabian government's efforts to deal with housing issues have grown in recent years. Given the current housing demand, the government recently has adopted objective reforms of the independent public housing operations comprising policymakers and other stakeholders. The efforts include supporting charitable organisations and nonprofit associations to contribute to social housing and the growing population in the housing sector $[38,39]$. Figure 1 shows the kind of housing developed in the KSA.

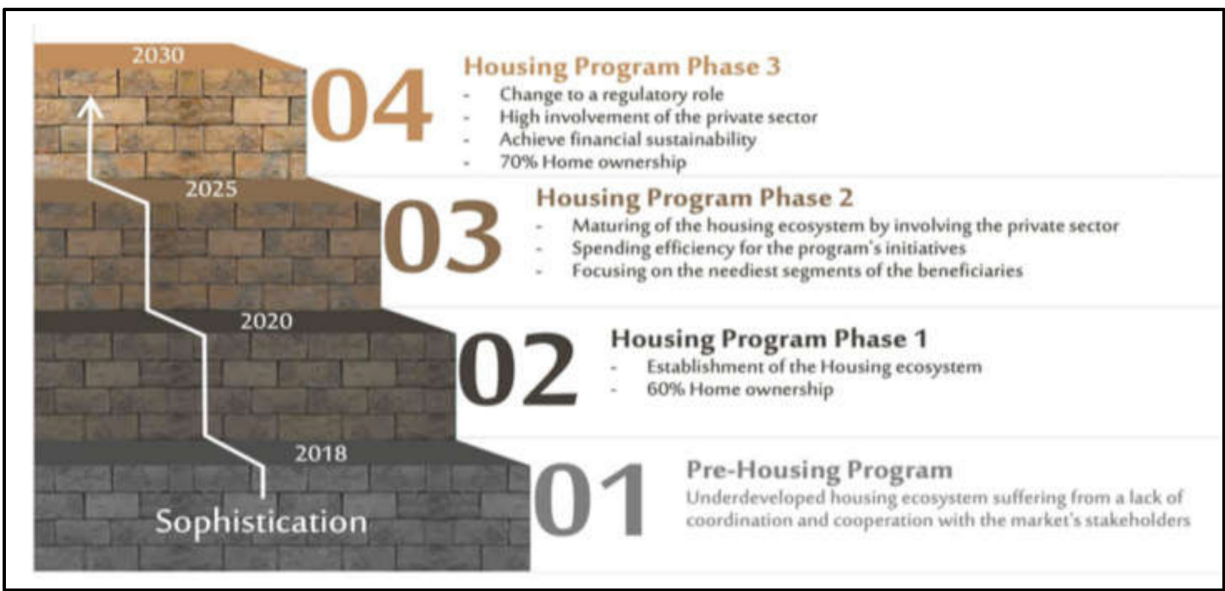

Figure 1. The program's 2030 roadmap [40].

This paper sets out to study the critical junctures of social housing policy in Saudi Arabia to trace its trajectory towards sustainability. It is contended that the deconstruction of historical timelines could provide useful insight into the capacities of the institutions and their readiness to adopt more sustainable practices in the housing sector under the Saudi Vision 2030. The KSA's ambitious 2030 vision within its overall framework aims to strengthen the kingdom's strengths. It also aims to transform it from an oil-based economy to more diverse economic regime. One of its long-term goals is to brew a suitable environment for Saudis to own appropriate housing, especially for the poor. This is in addition to increasing the efficiency and performance of the social services system. For an extended period of time, the kingdom has been less focused on social housing agenda. With this new vision, special programmes have been established for social housing, which seeks to activate the non-governmental role through co-production of housing outcomes [38]. 
Contributions to social housing studies take various forms in the Middle Eastern region [41]. Examining the role of critical junctures in housing policy development process is even rarer. Additionally, studies have often focused on the design, needs, and demographic characteristics of housing in Saudi Arabia [42,43]. In this paper, we attempt to investigate the social housing policy development process through the historical institutionalism lens portraying critical events and institutional mandates that influenced past decisions as well as paved the way for sustainable discourse. Historical studies of social housing policy journey are mostly limited to developed countries and are less focused on developing nations, while dissecting the policy evolution and critical junctures within resource-abundant Middle Eastern countries is even rarer.

The current section provides an overall background of the study, and a literature review on using the critical junctures approach in housing studies. The second section describes the study materials and methods, while the third demonstrates the study area. Then, the fourth section portrays and analyses the findings on the social housing policy development process in the KSA from 1930 until now. Following this, the last two sections discuss key findings, particularly the discussion section presents an invented historical timeline showing the housing policy development process and outcomes. Finally, the concluding remarks focus on tackling the challenges of the sustainability vision in the social housing sector and presenting lessons learned that are applicable for other countries.

\subsection{Literature on Historical Policy Development}

The theory of historical institutionalism suggests investigating critical junctures and drivers of policy transformation to inform policy development processes. The critical juncture is "the sudden changes at a certain point" describing policy evolution trajectories [44]. Capoccia and Kelemen [45] state that there is "institutional stability for long periods before a dramatic change, known as critical junctures". Therefore, it is an essential building block of historical institutionalism. Hogan [46] further notes that the "new institutionalism, and historical institutionalism in particular, has traditionally regarded the decisions made when an institution is formed, or policy initiated, as possessing a persistent influence".

Historical institutionalism is a widely adopted theoretical approach to understand policy change and for tracing the effects of the past on future policy regime. Historical institutionalism has been attempted through several approaches including path dependency, process tracing, and comparative historical analysis. These approaches share a common focus on historical events, interpreting its causation and effects on the subsequent outcome [47]. Studying historical milestones provides a baseline to evaluate subsequent policy direction [48]. The concept of path dependency has received greater attention in recent times to explain institutional theory through the works of Arthur, North and Krugman. Path dependence theorises "about the tendency of the effects of accumulated decisions to develop from an initial small difference into large cleavages in the free market, developed to explain path dependence with increasing returns" [44,45]. Political scientists and historical socialists engage this approach to explain the historical process by determining significant events and mechanisms within a national context. Path dependency analyses interactive sequences as the base event kicks off from a temporarily and causally bound value to a deterministic chain of events [48]. Path dependence literature relies on a critical juncture framework when institutional historicising focusses on events and milestones in policy development $[49,50]$. Critical juncture is used as an analytical tool in various contexts that often appears as a series of events including "sudden crisis and dramatic change" [51] that influences the identification of a situation or context and allows the interpretation of reality [52]. It is defined as "relatively short periods of time during which there is a substantially heightened probability that agents' choices will affect the outcome of interest" [45,52]. During the early periods of inception by Lipset and Rokkan [53], critical juncture was used to historicise the progression and maturity of political parties during the early stage of state building [54]. The critical juncture approach is useful to uncover the moments of transformation and underlying factors influencing planning decisions in 
the policy development process within centralised political environments [55], such as Saudi Arabia.

Path dependence theory has had a significant impact on evolutionary economics [56]. Institutional economists have also adopted theories based on an understanding of economic changes through path dependency. The QWERTY effect of typewriters [57] is often quoted to suggest how a specific sequence of technological development can be tracked to understand the course of economic changes. During the 1980s, path dependency was used in industrial fields to identify technologies that were not feasible in the industrial process, which disrupted the path of industrial development. Reliance on this concept had a significant impact on the development of the results based on tracing the history of operations [58]. On the other hand, historical institutionalism through critical junctures has been engaged to determine influential political decisions and institutional structures available to planners and policymakers [55]. Choi, Lee et al. [44] further note that "a political power is a clear exogenous factor in creating critical junctures in urban-planning and housing-policy". Such influence acts towards the institutional development through a short-term stepwise process. In the urban planning and housing literature, critical junctures define institutional change models and the development of a country's planning system by accumulating past events. While housing is mostly an inflexible sector as it requires long term investment and longer periods to realise policy outcomes [59], the social housing policy regime in Saudi Arabia has undergone a significant institutional transformation and delivery approach to address the increasing urbanisation and housing demand. It entails major policy change, promoting neo-liberal ideology and a progressive vision for sustainable policy outcomes. In this regard, this study undertakes a systematic historical investigation using the critical junctures concept in order to understand and assess the emerging policy decisions in the area of social housing in Saudi Arabia.

\section{Materials and Methods}

This paper aims to deconstruct the timeline of the social housing development process in Saudi Arabia tracing the critical junctures in shaping and directing towards an inclusive housing delivery approach, factors affecting institutional transformation and institutional readiness towards a sustainable and collaborative housing policy. In this regard, historical policy documents, academic literature and media reports have been reviewed to draw a historical timeline and to determine the policy directions. The article engages with a geographical area scarcely present in the current literature. Therefore, it brings a muchneeded comparative perspective for social housing policies from a country that is not part of the usual set of examples. The review includes several sources, manuscripts, and government documents to examine long historical periods.

Historicising the tradition of planning practice was developed by Dear [60]. He used the term deconstructing planning practice to reflect on concept, design and governance. We have adopted the idea of developing a cognitive map from Dear's work to deconstruct social housing policy trajectories for determining the critical junctures since the early days of the city development. In this regard, the investigation relied upon archival materials and historical policy documents related to housing development in the KSA. The policy documents were organised according to critical milestones in the history and major transformation in terms of development approach and policy shifts. The aim of the review was to understand policy influence, major practice and the impacts on the social housing sector within a particular time-period. A longer historical timeline developed through this review aided in detecting policy changes in line with the broader theoretical paradigms and to understand how the Vision 2030 has been crystalised over time.

Before 1970, the details were poorly recorded and recent literature was consulted who discussed the historical events. Other open access sources include historical documents and photo libraries [40]. After 1970, KSA started a more formal practice by introducing fiveyears-long planning and information process made available through government sources. The five-year planning documents (1970-2016) were critically reviewed to flesh out the 
historical timeline. Apart from these government documents, we also reviewed scholarly literature published on the Saudi and Middle Eastern social housing contexts to understand the debate, impacts on development and to bring some comparative perspectives.

\section{Study Area}

The KSA is a member of the Gulf Cooperation Council (GCC) and located in the heart of the Middle East. The country is surrounded by the United Arab Emirates and Qatar in the east; the Red Sea in the west; Kuwait, Iraq and Jordan in the north; Yemen and Oman in the south. Figure 2 shows the administrative boundary, major cities, and transportation routes of the KSA. The GCC states have a variety of social housing policies and practices within highly centralised and controlled political environments. The concept of social housing was marginally developed in this region during the past decades. Due to the resource abundance, many governments from this region initially approached the housing issue by providing supply-side subsidies. They have subsequently changed their approach towards providing demand-side support to serve their growing populations [61]. Al Nasiri [62] observes that while providing housing and facilitating people's own home ownership is still a top priority for all governments in this region, there remains a gap between formulating and implementing their social policies [63].

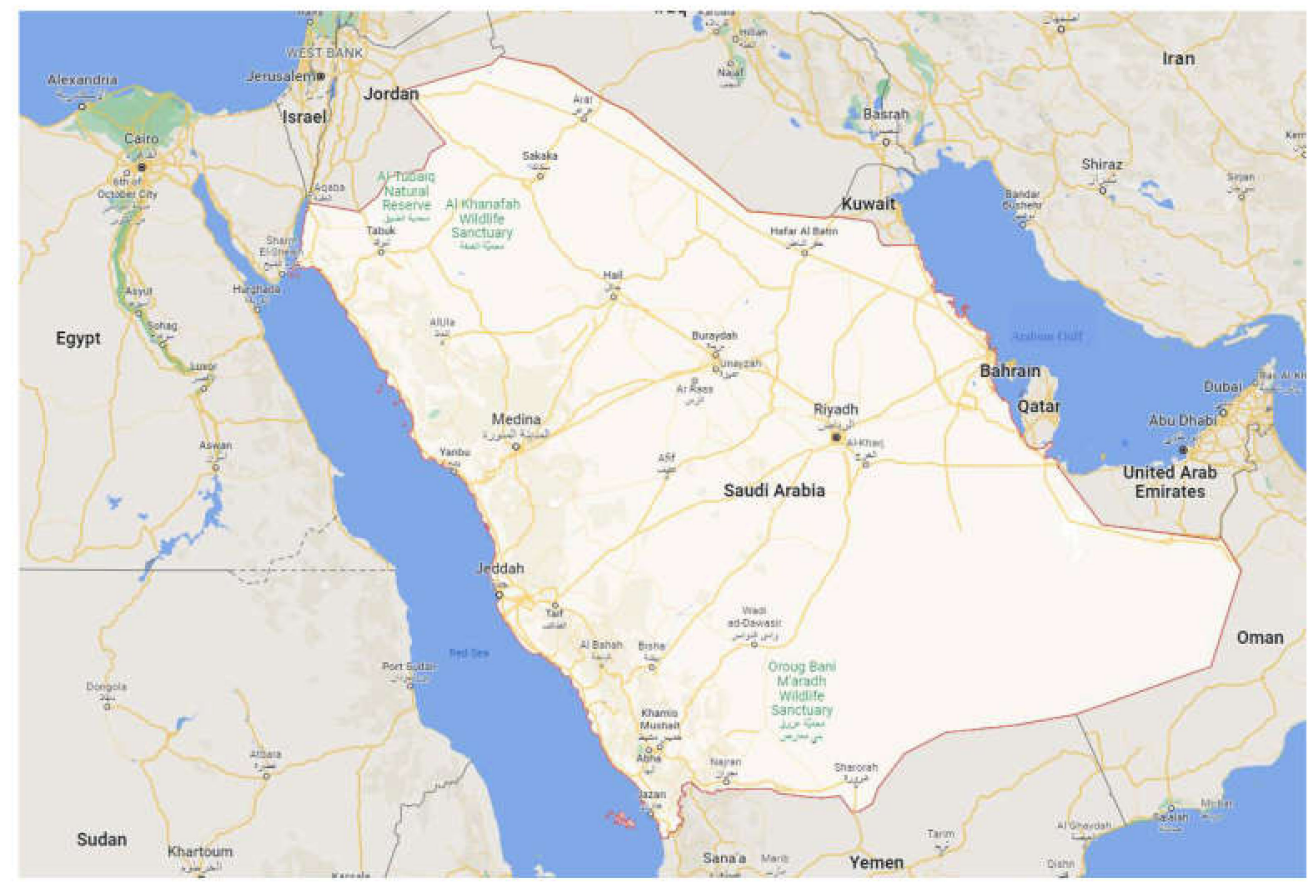

Figure 2. Administrative map of Saudi Arabia (collected from Google Maps).

The population growth in the GCC countries was among the world's highest for the period 1950 to 2000 [64] and the housing policies in the GCC countries are limited to citizens as the main targets; however, the impacts emanating from the influx of migrant workers have been significant on overall housing demand [63]. In the GCC, social housing took another turn where social housing is provided in the form of independent houses, unlike the high-rise buildings in some countries of the region [41]; however, the sector is comparatively less evolved due to the centralised governance structure and urban social fabric $[63,64]$. Moreover, the governments often fail to respond in determining the appropriate housing needs, especially for the disadvantaged population [43]. In the KSA, the largest country within GCC, the term "developmental housing" has been commonly used to define social housing as well as public or charitable housing [42]. Developmental housing refers to housing delivered by the government or with government funds to house the neediest citizens [43]. The history of social housing policies and approaches to housing the neediest 
citizens reveal critical junctures in policy change and reforms towards a neoliberal ideology in the country. While pursuing historical deconstruction of the social housing policies, in the next section we discuss the structural and ideological constraints and development opportunities since the foundation of the KSA in the early 20th century.

\section{Findings on the Social Housing Policy Development Process in the KSA}

\subsection{Pre-Unification Stage (Since 1930)}

In elementary framing, there had been efforts to settle nomads in specific locations which were aimed at improving their livelihood in the 1930s. It is considered one of the first initiatives to housing and settling the poor. Figure 3 shows a historic evidence of the distribution of major settlements in Saudi Arabia before the unification [65]. During this time, the KSA was not developed in terms of construction or planning and the people used to lead a nomadic life which was highly mobile and instable [42].

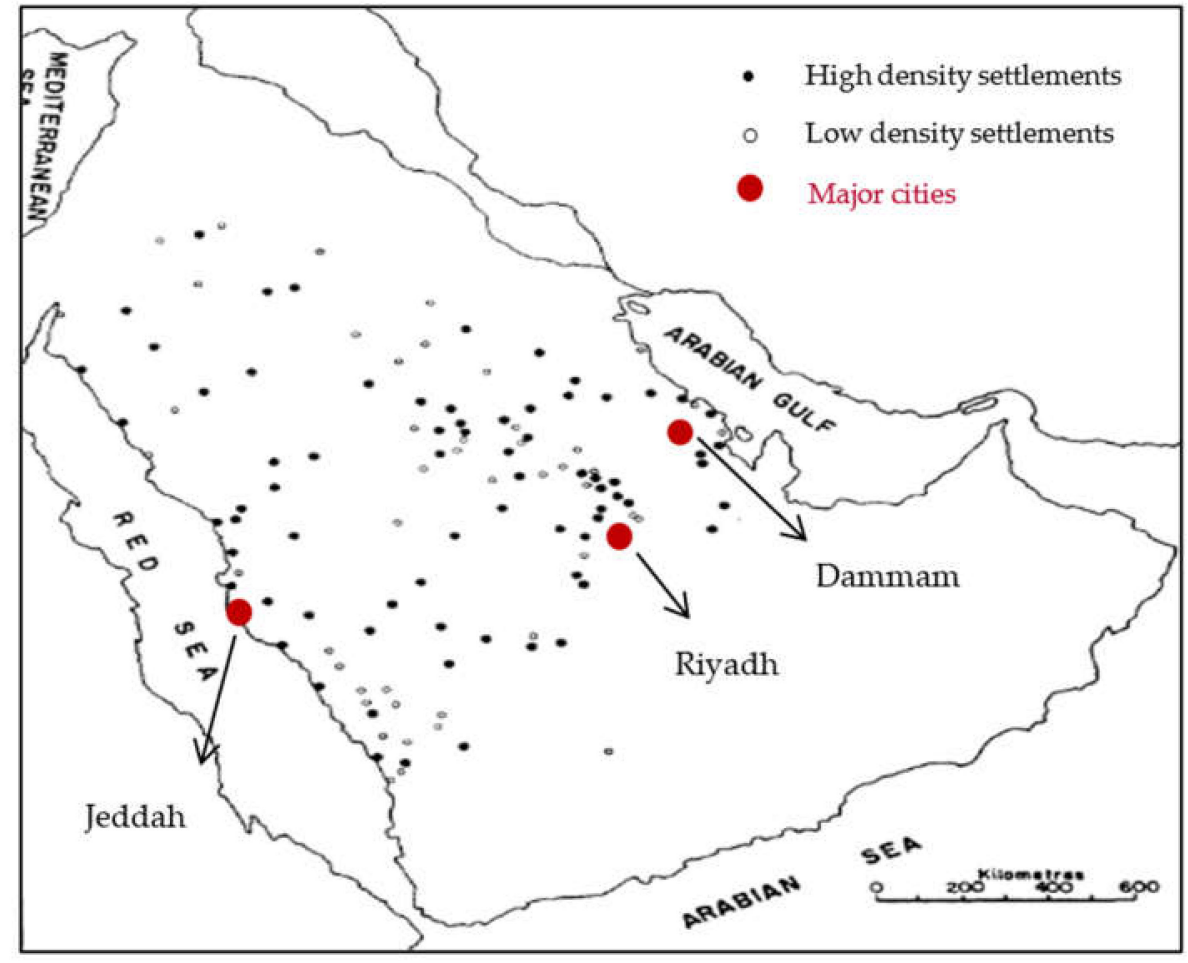

Figure 3. The distribution of major settlements in Saudi Arabia before the unification [66].

The KSA was characterised by very low urbanisation and was a predominantly nomadic society during the pre-unification stage [67]. Unlike other places, the holy cities of Mecca and Madinah observed an accelerated population growth and irregular housing development by religious settlers from abroad $[66,68]$. There was no formal planning system, and urban areas were mainly deprived of essential urban services. Figure 4a shows an example of old housing patterns in Riyadh inspired by the local environment. Figure $4 \mathrm{~b}$ shows the old urban residential style and housing lacking organised planning.

Soon after unification, oil was discovered but in non-commercial quantities in 1938. As a result, immigrants flocked to the cities for work opportunities which contributed to a "burgeoning housing demand" [70]. With the local market unable to respond to such pressure, this led to the growth of informal settlements and shantytowns. Figure 5a shows the urban pattern at the beginning of the emergence of the oil cities (Dhahran city 1936) [71]. 


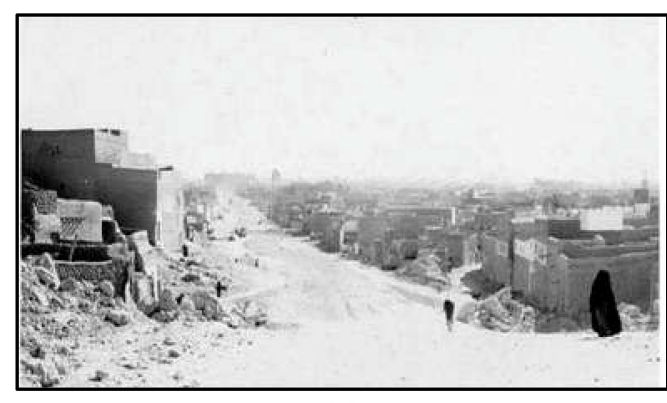

(a)

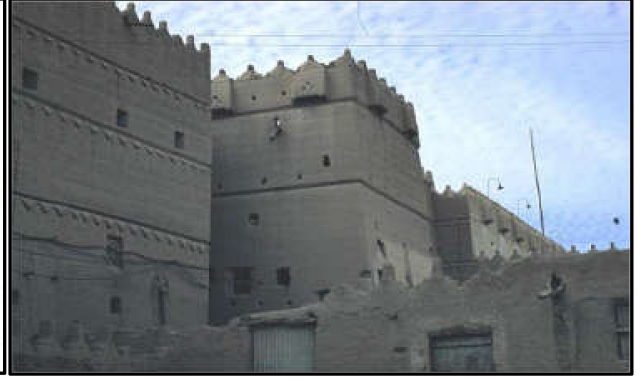

(b)

Figure 4. Examples of housing patterns in Riyadh city during the pre-unification stage. (a) An old housing patterns in Riyadh; (b) An old urban residential style [69].

\subsection{The Resource Dependent Path (1931-1969)}

The Saudi economy picked up quickly after the WWII, and the state commissioned the Aramco Company (formerly Arabian-American Oil Company) to streamline extraction and business operations. With significant commercialisation of oil resources, Aramco engaged in organised land subdivision and housing development for foreign business groups. Figure 5b shows Aramco's housing pattern and planning for Dhahran in 1949, increasing the number of housing units allocated to employees [71]. The local and immigrant labourers were housed in dormitories, and "married workers occupied outlying areas of American "planned" oil towns and nearby traditional oasis towns" [70]. Such arrangements inflicted anxiety among local workers. Consequently, the government compelled Aramco to launch a 'Home Ownership Programme' in the early 1950s on public land with the provision of interest-free grants for its employees [42]. The initiative turned out to be a popular strategy and offered 41,400 single family residential units by 1999 [70]. To address the local housing needs and the demand of increasing immigrant workers, the government scrambled to establish the first public housing project in Riyadh in 1953 [42]. Subsequently, the government moved to a more formal and direct intervention for housing development. The direct approach included the construction of high-rise public housing that was heavily criticised due to its non-sensitivity towards the local culture and design preferences. The scheme was further supported by the option of granting free lands for the citizens as the number of migrant workers was mounting [42].

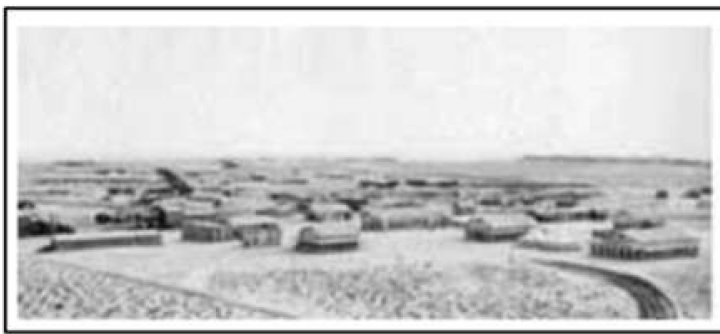

(a)

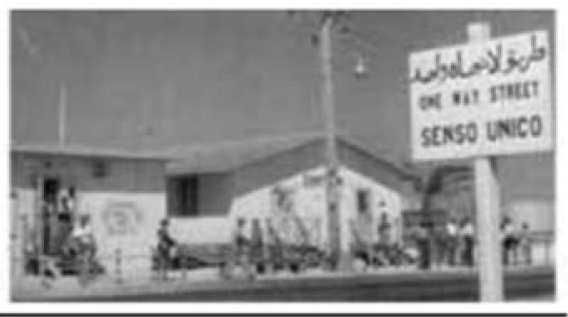

(b)

Figure 5. The development of workers' housing in the city of Dhahran. (a) The housing pattern at the beginning of the emergence of the oil cities (1936); (b) Residential pattern of oil company employees in Dhahran in (1949) [71].

In 1957, all ministries moved to Riyadh, and the government housed its employees in the new housing project with better urban facilities [42]. Figure 6 shows the new ministries buildings in the city of Riyadh. In the 1960s, municipalities were established in major cities to roll out formal and organised urban planning and development interventions. The Central Planning Commission (CPC) emanating from the Supreme Planning Council arose in 1964 to set economic development plans. Several strategic reports and plans were released from the CPC to support and improve the Saudi economy and future development. The 
Five-Year Development Plans were the most notable strategies initiated in 1970, releasing nine comprehensive development plans until 2015 [42].

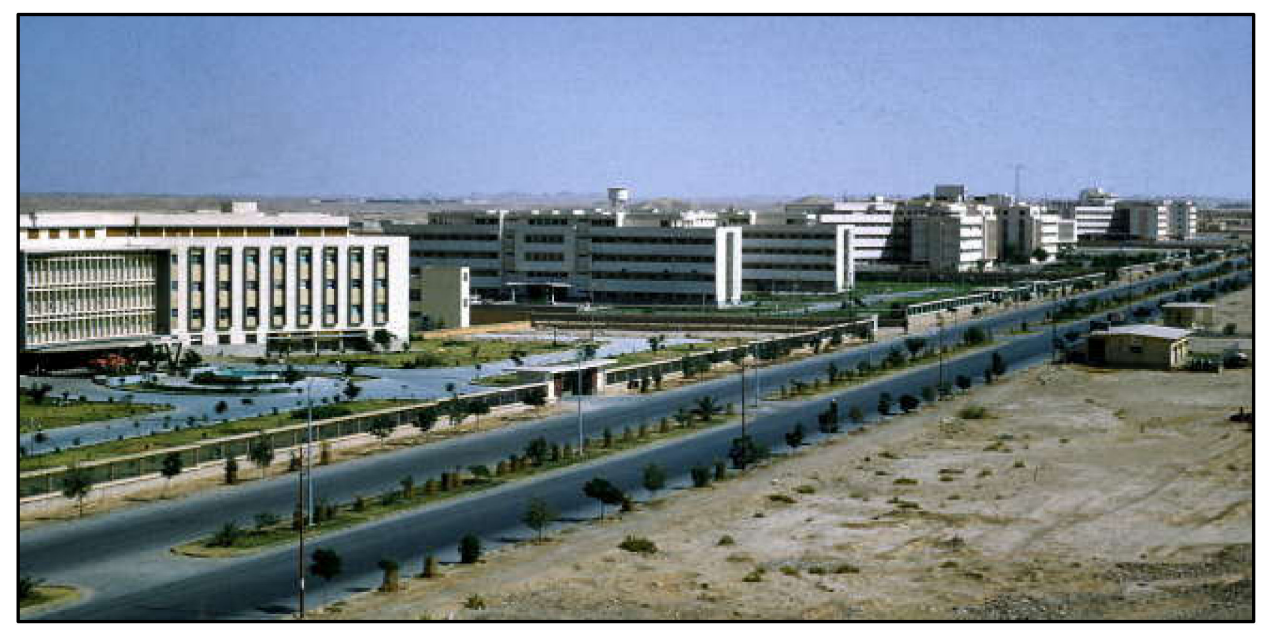

Figure 6. The new ministries complex [69].

\subsection{Critical Junctures and an Evolving Housing Strategy (1970-1995)}

The term 'public housing' was first adopted by the Saudi government in the 1970s to denote housing for government employees [72]. The Saudi government's golden era of economic boom started with the dramatic increase of oil prices in the international market. The state invested an estimated amount of USD 500 billion in massive infrastructure development projects across the country [73]. The First Five-Year Development Plan (19701975) focused on the institutionalised response to tackle housing issues. In this regard, the General Administration of Housing was established in 1971. Later, there was a shift from a direct housing strategy to an indirect approach to attain economic viability in housing delivery. In 1974, an indirect approach materialised through establishing the Real Estate Development Fund (REDF), provisioning USD 66 million in housing loans with zero interest for citizens $[42,74]$. The Aramco Company also adopted a similar approach to serving their workers in major oil regions. The overall housing policy aimed at achieving social welfare utilising a series of medium and long-term financial mechanisms [75]. Figure 7a,b shows some new housing patterns where the government adopted multi-story buildings projects in several cities during this period.

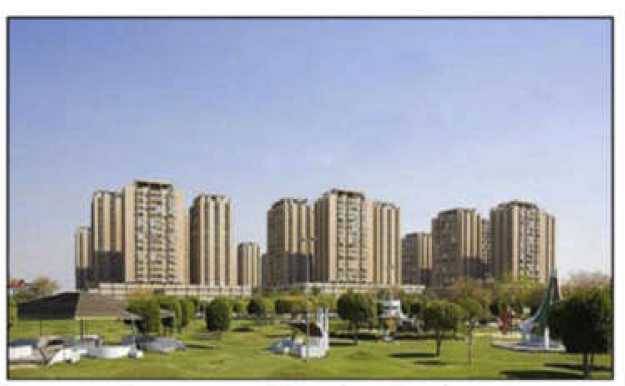

(a) Multi-storey buildings models in Dammam

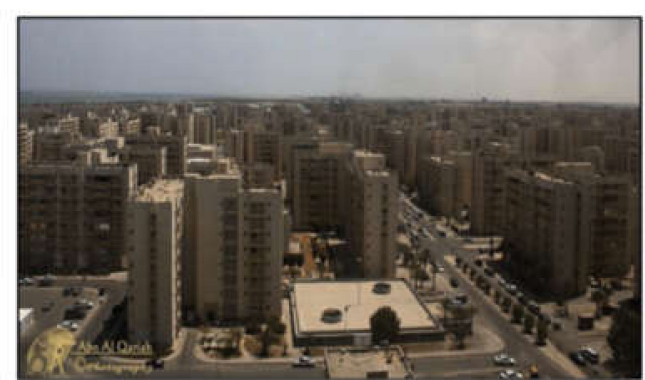

(b) Multi-storey buildings models in Al Khobar

Figure 7. Government housing projects in a number of major cities [76].

The REDF offered loans to individuals and institutions to establish real estate projects for private or commercial use. The support was conditional such as owning land and having a job to ensure repayment of the loan [77]. While the REDF contributed significantly to housing development in the country, the financial supply and land release encountered significant delays and could not cope with the increasing housing demand. A massive influx of overseas workers and migration of the local population to the major cities for a better 
lifestyle contributed to an exponential growth of the urban population and subsequent housing shortage [78]. The situation was exacerbated with the higher land price and upward rental market trends in the 1970s [42,75].

The Second Five Year Development Plan (1975-1980) established the Ministry of Public Works and Housing (MPWH) in 1975 to streamline the housing management system and also introduced the Municipal Land Grants Programme (MLGP), which recommended 44,000 lots for low-income Saudi nationals to construct their dwellings [79]. Therefore, the state housing policy circled around both direct (housing delivery and free land) and indirect approaches (e.g., through the REDF) to tackle the critical housing shortage. The state policy continued to emphasise social welfare and equity by creating a balance between housing supply and demand, raising homeownership up to $75 \%$ and ensuring more affordable housing where housing-related expenditure remained below $20 \%$ of the household's total income. In addition, $50 \%$ of the newly constructed 122,000 housing units were allocated for society's neediest groups [75]. Table 1 shows the goals and achievements in the housing sector during the second development plan.

Table 1. Goals and achievements in the housing sector during the second development plan [80].

\begin{tabular}{cccc}
\hline Accommodation & $\begin{array}{c}\text { Second Plan Target } \\
\text { (Housing Units) }\end{array}$ & $\begin{array}{c}\text { Second Plan } \\
\text { Achievement } \\
\text { (Housing Units) }\end{array}$ & $\begin{array}{c}\text { Target Achievement } \\
\text { Ratio (\%) }\end{array}$ \\
\hline $\begin{array}{c}\text { Permanent residences } \\
\text { (Public sector) }\end{array}$ & 25,500 & 53,600 & $210 \%$ \\
$\begin{array}{c}\text { Permanent residences } \\
\text { (Private sector) }\end{array}$ & 122,100 & 150,000 & $123 \%$ \\
$\begin{array}{c}\text { Temporary housing } \\
\text { for projects } \\
\text { Total }\end{array}$ & 51,000 & 51,000 & $100 \%$ \\
\hline
\end{tabular}

The REDF faced declining funding and the resulting housing projects drew criticism for not considering local culture, family composition, and housing preference. This is understood as mainly resulting from a rush to deliver" public housing projects" to quickly fix the housing problem $[70,78]$.

\subsection{The Rise of Neo-Liberalism (1995-2005)}

Another critical juncture in Saudi housing policy development relates to the Sixth National Five-Year Development Plan (1995-2000), which enabled the private sector to play an active role in housing development. This basically came as a support as government subsidies for housing tended to decline and the construction of housing units by state agencies decreased significantly. For example, the REDF was reduced considerably to an average of 7,581 (loans per year) compared to 153,320 (loans per year) in the first and second Five-Year Development Plans [80]. Commercial banks that emerged as a shareholder in the housing process to support citizens within a diminishing role of the state, however, operated under strict government regulations. Mubarak [70] reports that,

... central government regulations, which limit the number of years for amortizing mortgages on housing loans to seven years, have not been changed to accommodate the Plan's promulgation. To date, banks are still not allowed to extend the time period of seven years. (p.9)

Due to the religious restrictions under the conservative government regime, an interestbased mortgage system failed to develop. As a result, middle and low-income citizens faced challenges in securing adequate housing. Moreover, while the state's support for the REDF declined, the queue on the support list only increased [80]. Consequently, the Seventh Five-Year Development Plan (2000-2005) noted that the lack of financial sustainability to support the REDF and the length of time required to obtain new loans were fundamental issues that needed to be addressed. Given the difficulties faced by middle and low-income 
citizens, new policies were adopted to provide land at reasonable prices and expedite the disbursing of loans to the neediest groups. In some instances, it was suggested to provide financial support to these groups through special programs. Further, a streamlined building code was issued to reduce housing construction and maintenance costs [80]. In the early years of the new millennium, many charitable foundations emerged that offered free accommodation for the poor [81].

\subsection{The Fall of Public Housing and Institutional Transformation (2005-2015)}

The Eighth Five-Year Development Plan (2005-2010) sought to develop a policy that strengthened the relationship between population variables and sustainable development trends. Population policies were adopted that sought to consider the quantitative and qualitative variables of the population and their distribution [82]. Additionally, substantial funding amounting to USD 10.6 billion was allocated to promote municipal services and housing [82]. Due to the importance given to the housing sector and the rapid population growth, the General Housing Authority (GHA) was established in 2007 [83]. The housing sector was restructured during the Eighth Five-Year Development Plan, for effective institutional and organisational development of the sector. The GHA took over the housing development portfolio and embarked upon several strategies to further regularise the system. It included sustaining the supply of residential land and targeting increased homeownership numbers. Several regulations and policies were proposed to deliver appropriate housing facilities for low-income people. Furthermore, support for the REDF and the approval and implementation of real estate financing regulations enabled the private sector to support housing interventions [83]. This plan targeted several developmental housing programmes for the first time. In 2006, USD 2.6 billion was invested in providing 66,000 housing units under this programme. In the following year, the authority of the developmental housing programme was transferred to the Ministry of Social Affairs and then again handed to the GHA. The GHA contributed to shaping the future housing policy framework and launched the first developmental housing projects in some major cities, including 1619 units for low-income groups [69]; however, there were delays in delivering the developmental housing projects. According to the Ministry of Economy and Planning, the stagnated implementation resulted, firstly, from the insufficiency of private real estate financing and secondly, from the limitations of the entities that provide housing for their employees in the public and private sectors [83].

This period observed significant changes in the socio-cultural context and acute housing problems, including a higher unemployment rate, inadequate and unaffordable housing, low levels of homeownership and lack of financial support for residential development [84]. The traditional housing delivery patterns and application of non-pragmatic policies struggled to cope with the emerging urban challenges. Around this time, several failures of state-funded public housing projects were noted in the literature advocating for an inclusive and sustainable policy framework to engage the beneficiaries in the planning process of the public agenda [85]. In response to the shortfalls of the previous plan, the Ninth Five-Year Development Plan (2010-2015) called for a national housing strategy focusing on low-income groups and highlighted the role of the private sector [84]. The plan was targeted to meet $80 \%$ of the total housing demand (1.25 million housing units) [84] (Table 2). In 2011, the GHA transformed into the Ministry of Housing to better coordinate the housing sector. The government sought to support it with exceptional funding to tackle the cumulative effects of the previous plans. For example, the REDF fund was realigned, and a total of USD 10.6 billion was injected for effectiveness and timely loan disbursement [79]. Indeed, the government allocated around USD 66.6 billion for this purpose $[63,64]$. Nevertheless, this development plan faced several challenges regarding the adequacy of housing supply, with increasing homeownership, managing the pricing levels for land and housing units, and ensuring financial sustainability [84]. A Tenth Five-Year Development Plan was subsequently proposed to provide adequate housing for all with a notable contribution from 
the private sector. The tenth plan was, however, discontinued and replaced by the current Vision 2030 [84].

Table 2. The estimated housing demand during the Ninth development plan.

\begin{tabular}{cc}
\hline Housing Demand & Ninth Plan Target (Housing Units) * \\
\hline New housing units for Saudis & 800,000 \\
New housing units for non-Saudis & 200,000 \\
Housing units to meet the demand carried & 70,000 \\
forward from the Eighth Development Plan & 70,000 \\
Residential units required for replacement & 110,000 \\
10\% reserve units to ease rent inflation & $1,250,000$ \\
Total & ${ }^{*}$ No data for ninth plan achievement in the tenth plan because tenth plan was discontinued and replaced by the
\end{tabular}
current Vision 2030 [83].

\subsection{Vision 2030 (2016 Onward)}

The KSA has experienced unprecedented urbanisation since the foundation of the country in the 1930s, when it was below 10\%. It reached $21 \%$ in the 1950 s and in 2014 it was reported to be around 85\% [42]. By the end of the nine Five-Year Development Plans, the overwhelming demand for housing had reached 1.45 million, among which $15 \%$ represented disadvantaged groups, including families comprising widows, orphans, seniors, and low-income people. In the last decade, disparity between the housing supply and demand became wider than ever before. The REDF has been exhausted, with a long queue of families (over 62,000 applications) waiting for housing loans [86,87]. Moreover, "the pressure on the supply side for middle- and low-class housing remains unaddressed" [85]. It is reported that due to the lack of specific eligibility criteria to determine disadvantaged beneficiaries, many users resorted to circumventing housing regulations [88]. The instability of overall housing policies in the KSA reflected the government's struggle to manage an unprecedented urbanisation and in-migration of foreign workers, particularly in oil-related industries. While the state had continued to support the real estate monopolies since the oil boom, affordable housing for the neediest remained far behind due to the speculation of the housing market.

To quickly respond to this stagnant situation, the Ministry of Housing returned to a direct housing delivery approach instead of promoting housing loan schemes. This was also followed by initiating a series of recent subsidies and cuts. Due to unstable oil prices over past years, the budget deficit of the Kingdom further complicates the housing market [89]. As a result, the authorities decided to reduce the funds earmarked for providing housing subsidies. There has been a realisation that low-income families suffered as the housing prices remained beyond their purchasing capacity even as the overall target of housing supply was sufficiently met [90]. In 2016, the state embarked upon a new mission by introducing a post-oil plan to strengthen its effort for an adequate and affordable housing provision, particularly for the people most in need. The policy seeks to address the limitations of previous plans and housing strategies by (i) considering the socio-economic context of the beneficiaries to determine appropriate housing design; (ii) increasing state support to house low and middle-income citizens through the enhanced resourcing of REDF and finally (iii) promoting partnerships and cooperation with the private and non-profit (charitable organisations) sectors [12]. This has also been facilitated by the commitment to ensure institutional efficiency and an appropriate policy framework based on neo-liberal ideology in the housing sector (MOH 2020a). The UN [84] further highlights that "the Ministry of Housing is approaching such [public-private] partnerships by strengthening regulatory frameworks and offer incentives to the private sectors to construct social housing".

The concept of developmental housing has been further reiterated through Vision 2030 [91]. The developmental housing initiative focuses on encouraging contribution from the non-profit sector through agreements of cooperation [88]. There is a deliberate acknowl- 
edgment of the positive contribution civil society groups, such as charitable organisations, can make in housing provision. While the government plans to achieve $70 \%$ homeownership in this long-term strategy, unprivileged citizens are to receive the utmost priority [38]. Finally, the Saudi Vision 2030 for Comprehensive Development plans did not neglect meeting sustainability needs. Indeed, the rapid urban and residential development aspect has considered many aspects concerning sustainability for newer generations of social houses. This is in addition to adopting social housing designs that keep pace with modernity and move away from traditional housing such as high-density residential buildings [38-40]

\section{Discussion}

A deconstruction of the timeline shows that social housing as a structured and planned concept did not appear until the beginning of the last century. The initial efforts were restricted to housing the lower working class in the cities [24] (Figure 8). It was mainly aimed at housing the working poor to increase and improve industrial production. Historically, working-class housing began in Europe during the sixteenth century, specifically in Germany. The idea gradually developed until workers' housing or so-called company towns appeared in the nineteenth century. It aimed to create affordable housing by company and industry owners for their workers [17]. Czischke and Gruis [28] state that the demand for housing was the result of the industrial revolution and rapid urban growth. Therefore, due to the urgent housing needs that appeared in Europe, the idea of social housing arose.

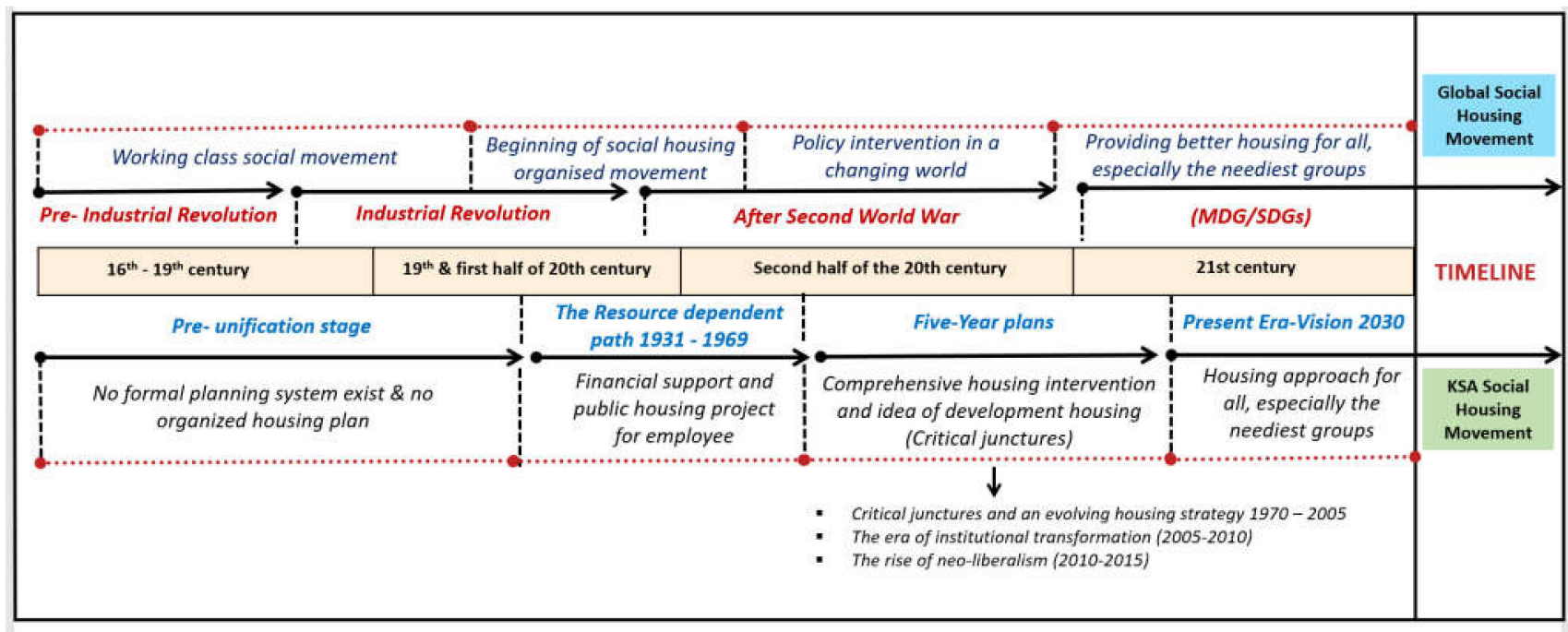

Figure 8. Historical timeline of social housing policy development in Saudi Arabia.

Efforts moved from a philanthropic perspective to industrial interests shaping the social housing policies applied by many governments; however, dire economic conditions caused by the two world wars caused development and social housing policies to take a different turn. Although the state's strategic move was generous and promising, Kyriazis and Balasis [85] point out that, "this political tactic was not strategically matched by a parallel concern regarding chronic high unemployment rates, extreme social segregation, and scanty housing". Even though a common goal for social housing is observed globally, each country has contributed to setting and developing policies commensurate with its capabilities and their way of defining social housing as well as the targeted groups in their societies. Additionally, different terminologies have also been used for social housing in most European Union countries.

The USA has followed a similar path in developing social housing policies over the centuries. Recently, it is also apparent that many countries have taken a more neo-liberal policy approach to involve many commercial and non-profit actors in providing social housing. Regardless of its success or not in delivering social housing, tangible changes 
have developed over time. As for social housing providers, most countries directed social housing towards the market, especially in the European Union after World War II. Evolution and changes followed in these policies with new ideas such as co-production, rental housing, etc., and this has led to variation in the states' commitment to full or limited financing for social housing and enhanced involvements of community organisations. Similarly, many countries have applied new policies to reduce subsidies and to involve the private sector, as has happened in the USA.

The historical analysis further reveals a transformation in housing types and settlement patterns. In the 1930s and 1940s, the oil company contributed to the construction and planning as it was an American company in its early years, and most of its employees were American. Therefore, the development started with the cities close to oil wells designed as an American housing pattern, as shown in Figure 4. Later, the housing construction design evolved within the traditional Saudi style of a two-storey concrete dwelling, as shown in Figure 5. This residential architectural style has been prevailing up until now, but it has also been redeveloped and improved. Additionally, the multi-storey buildings still exist today and are similar to those in many countries, as shown in Figure 6.

On the contrary, there is a significant gap in developing social housing policies in the KSA compared to the global context. The social housing policy development in the KSA indicating the critical junctures is summarised across the global timeline in Figure 8. It was found that social housing in the KSA has evolved as a concept, although this term, per se, has not been used in the local context. In the last century, the state began to settle nomads after the unification of the kingdom. Then, financial support projects and public housing for employees started with the discovery of oil and economic prosperity between the 1930s and 1960s. In the 1970s and 1980s, developmental housing programs appeared as the first measure taken to house poor and low-income families and since then 'developmental housing' has been the most often used term to refer to the social housing concept. The government has mainly supported development housing in an inflexible manner, with a minor contribution by some charitable organisations to house the neediest groups at the onset of the new millennium. While housing support policies have evolved over time, it is only in the past few years that policies focus on delivering various programs to support families most in need of housing. In 2016, the urgent need to focus on housing the neediest groups were acknowledged and included in the Kingdom's Vision 2030. The KSA Vision 2030 has incorporated goals that seek various bodies' participation in developing developmental housing policies. Moreover, emphasis is also given to address any weaknesses that could undermine sustained support for the provision of developmental housing.

The historical timeline of the Saudi social housing policies progression reveals several critical junctures characterised by the central political act and resource dependency. The brief analysis of the historical context presented in the earlier sections demonstrates how emergency events have contributed to the development and changes in housing policy directions. The stages of social housing development demonstrate how the critical junctures led to policy change from a direct to an indirect housing approach before finally moving into the sustainable development lexicon through public-private partnership and a socially responsive policy framework.

\section{Conclusions}

KSA's Vision 2030 seeks to reform and continuously develop all aspects of development, most importantly the housing sector. In line with the vision, the government's strategic goal is to provide opportunities for Saudi families to own adequate housing. The vision requires the acceleration of steps in reforming and developing housing policy and keeping pace with housing demand through many programs and initiatives for all segments of society [38]. The state has sought to transform its role from a renter state to a welfare state. The welfare state, however, is widely believed to be unsustainable, especially if it depends on unstable oil incomes in a society with a young and rapidly growing population. The Vision 2030, therefore, seeks to accelerate the pace of economic 
reform, which significantly aims to diversify other sources of income instead of solely relying on oil income. Successful economic diversification could, thus, create sustainability and continuity in addressing housing issues in the future.

Perhaps the most prominent reason for such reform is related to the increase in the budget deficit in the state [39]. Recently, revenues have fallen dramatically, sounding the alarm bell regarding the massive drop in world oil prices. The budget deficit increased and continued to fluctuate until the deficit reached SAR 297 billion in 2016 [92]. Nevertheless, with the adoption of the vision approved in 2016, economic reform has improved. Additionally, the state's income has diversified, and the dependence on oil incomes has declined. As a result of this vision, the deficit declined in recent years until reaching SAR 132.6 billion by 2019. Moreover, another driving force is associated with the increased number of expatriates and their families that have contributed to the large number of the non-Saudi population, estimated to be around one-third of the total population (around 37\%) in 2016 [93,94]. Thus, the demand for housing by this demographic section impacts the housing market significantly at present and will continue to do so in the future. This rise in the population of expatriates has caused demand to exceed supply, causing an increase in rental rates and the consequent increase in the prices of land and residential units for sale.

Whilst in the past, the government attempted to resolve housing issues without seeking intervention from any other party, the Vision 2030 signals the government's adoption of a neo-liberal approach towards seeking multi-stakeholder partnerships. Since 2016, the state has been persistently working through building an integrated institutional response stepping beyond the traditional non-flexible policy environment. A collaborative approach stemming from the new vision has become an essential factor for continued economic sustainability in the state. Responding to the key objectives of Vision 2030, several initiatives and programs have been established under the supervision of the Ministry of Municipal and Rural Affairs and Housing. A major difference in the case of KSA, compared to most developing countries, is that while the government is beginning to pull back on public welfare expenditure in line with neoliberal thinking, it is still prepared to make substantial financial investments. This places the government in the position to determine the supervisory framework within which private sector and civil society groups could collaborate. The supervision includes oversight of legislative, organisational, administrative and financial aspects of the housing programs. Consequently, such supervisory arrangements could be workable as long as sufficient room is built in for other non-government actors to work within their specific protocols and frameworks as they collaborate to provide affordable and appropriate housing for the neediest sections of society. Moreover, building effective partnerships with the private sector, non-profit organisations, and charitable organisations will reflect positively on society and will ensure the long-term sustainability of services.

Finally, there are many lessons learned through which sustainability can be visualised in policies and understanding the best methods and theories of how policies are shaped and changed over time, namely, through the so-called critical junctures, and there are many lessons learned by reviewing much of the literature. In terms of sustainability, it is an effective method if used appropriately. One of the lessons learned is understanding sustainable solutions by supporting clear policies that are scalable and innovative. It is essential to educate and draw attention to highlight the importance and benefits of sustainability in social housing. Additionally, it is also better to know that policies should be aligned with innovative sustainable solutions and that the collective work of stakeholders enhances the understanding of future visions to achieve a commitment to sustainability for adequate social housing.

Author Contributions: The study was conceptualized by K.A.M.A.M., who also contributed to the introduction, critical junctures in the KSA and discussion section. M.S.H.S. performed the literature review and framing the global history of social housing. S.K. contributed to the discussion and conclusion section and overall editing. All authors have read and agreed to the published version of the manuscript. 
Funding: This research received no external funding.

Institutional Review Board Statement: Not applicable.

Informed Consent Statement: Not applicable.

Data Availability Statement: Not applicable.

Conflicts of Interest: The authors declare no conflict of interest.

\section{References}

1. Alqahtany, A. People's perceptions of sustainable housing in developing countries: The case of Riyadh, Saudi Arabia. Hous. Care Support 2020, 23, 93-109. [CrossRef]

2. Ritchie, H.; Roser, M. Urbanization. 2018. Available online: https://ourworldindata.org/urbanization (accessed on 10 August 2021).

3. Saldaña-Márquez, H.; Gómez-Soberón, J.M.; Arredondo-Rea, S.P.; Gámez-García, D.C.; Corral-Higuera, R. Sustainable social housing: The comparison of the Mexican funding program for housing solutions and building sustainability rating systems. Build. Environ. 2018, 133, 103-122. [CrossRef]

4. Mitlin, D.; Mogaladi, J. Social movements and the struggle for shelter: A case study of eThekwini (Durban). Prog. Plan. 2013, 84, 1-39. [CrossRef] [PubMed]

5. Kraatz, J.A.; Mitchell, J.; Matan, A.; Newman, P. Rethinking Social Housing: Efficient, Effective and Equitable. 2015. Sustainable Built Environment National Research Centre: Perth. Available online: https://sbenrc.com.au/app/uploads/2014/09/1.31 -Industry_Progress-Report-1-FINAL-020315.pdf (accessed on 10 August 2021).

6. Vale, L.J.; Shamsuddin, S.; Gray, A.; Bertumen, K. What affordable housing should afford: Housing for resilient cities. Cityscape 2014, 16, 21-50.

7. Kellett, R.; Christen, A.; Coops, N.C.; van der Laan, M.; Crawford, B.; Tooke, T.R.; Olchovski, I. A systems approach to carbon cycling and emissions modeling at an urban neighborhood scale. Landsc. Urban Plan. 2013, 110, 48-58. [CrossRef]

8. Miraftab, F. Insurgent Planning: Situating Radical Planning in the Global South. Plan. Theory 2009, 8, 32-50. [CrossRef]

9. United Nation Development Programme. Revision of World Urbanization Prospects; Department of Economic and Social Affairs, Population Dynamics. 2018. Available online: https://population.un.org/wup/ (accessed on 11 August 2021).

10. Woodcraft, S.; Hackett, T.; Caistor-Arendar, L. Design for Social Sustainability: A Framework for Creating Thriving New Communities; The Young Foundation: London, UK, 2012.

11. Bonetti, M. Sustainable Social Housing Initiative (SUSHI); United Nations Environment Programme: New York, NY, USA, 2009.

12. Alqahtany, A. Affordable housing in Saudi Arabia's vision 2030: New developments and new challenges. Int. J. Hous. Mark. Anal. 2021, 14, 243-256. [CrossRef]

13. Suttor, G. Canadian Social Housing: Policy Evolution and Impacts on the Housing System and Urban Space; University of Toronto: Toronto, ON, Canada, 2014.

14. Scanlon, K.; Arrigoitia, M.F.; Whitehead, C.M. Social housing in Europe. Eur. Policy Anal. 2015, 17, 1-12.

15. Prentice, D.; Scutella, R. What are the impacts of living in social housing? New evidence from Australia. Hous. Stud. 2019, 35, 612-647. [CrossRef]

16. Tunstall, R.K.; Pleace, N. Social Housing: Evidence Review; University of York: York, UK, 2018.

17. Amirjani, R. Shushtar New Town: A Turning Point in Iranian Social Housing History; University of Canberra: Canberra, Australia, 2020.

18. Lévy-Vroelant, C.; Reinprecht, C.; Robertson, D.; Wassenberg, F. Learning from history: 'Path dependency' and change in the social housing sectors of Austria, France, the Netherlands and Scotland. In Social housing in Europe; LSE/Wiley: London, UK, 2013.

19. Poggio, T.; Whitehead, C. Social Housing in Europe: Legacies, New Trends and the Crisis. Crit. Hous. Anal. 2017, 4, 1-10. [CrossRef]

20. Peppercorn, I.; Taffin, C. Social housing in the USA and France: Lessons from convergences and divergences. Urban Plan. Int. 2009, 3, 25-30.

21. Gowan, P.; Cooper, R. Social Housing in the United States; People's Policy Project: Dublin, Ireland, 2018.

22. Collinson, R.; Ellen, I.G.; Ludwig, J. Low-income housing policy. In Economics of Means-Tested Transfer Programs in the United States; University of Chicago Press: Chicago, IL, USA, 2015; Volume 2, pp. 59-126.

23. Bratt, R.G. The Role of Nonprofits in Meeting the Housing Challenge in the United States. Urban Res. Pr. 2017, 12, 7-37. [CrossRef]

24. Stoloff, J.A. A brief history of public housing. In Proceedings of the annual meeting of the American Sociological Association, San Francisco, CA, USA, 9 August 2004.

25. Tombs, R. The English and Their History; Penguin Books Limited: London, UK, 2014.

26. Cole, I. Hidden from History? Housing Studies, the Perpetual Present and the Case of Social Housing in Britain. Hous. Stud. 2006, 21, 283-295. [CrossRef]

27. Lambert, D. Some Practical Difficulties of Implementing Social Mix. Hous. Res. Hous. Auth. 1979, 2, 9-18.

28. Czischke, D.; Gruis, V. Managing Social Rental Housing in the EU in a Changing Policy Environment: Towards a Comparative Study. In Comparative Housing Policy; European Network for Housing Research: Dublin, Ireland, 2007. 
29. Pestoff, V. Co-production and Third Sector Social Services in Europe: Some Concepts and Evidence. Volunt. Int. J. Volunt. Nonprofit Organ. 2012, 23, 1102-1118. [CrossRef]

30. Ives, A. Neoliberalism and the concept of governance: Renewing with an older liberal tradition to legitimate the power of capital. Mémoire(s) Identité(s), Marg. Eacute(s) Dans Le Monde Occident. Contemp. 2015, 2, 14. [CrossRef]

31. Gertz, G.; Kharas, H. Beyond Neoliberalism: Insights from Emerging Markets; Brookings Institution: Melbourne, Australia, 2019.

32. Topal, A. Global Processes and Local Consequences of Decentralization: A Sub-national Comparison in Mexico. Reg. Stud. 2013, 49, 1126-1139. [CrossRef]

33. Sellers, J.M.; Lidström, A. Decentralization, Local Government, and the Welfare State. Governance 2007, 20, 609-632. [CrossRef]

34. Opoku, R.A.; Abdul-Muhmin, A.G. Housing preferences and attribute importance among low-income consumers in Saudi Arabia. Habitat Int. 2010, 34, 219-227. [CrossRef]

35. Edwards, M. Prospects for Land, Rent and Housing in UK Cities; Regional Studies Association: London, UK, 2015.

36. Center for strategic prevention support. Implementing Promising Community Interventions. 2020. Available online: https: / / ctb.ku.edu/en/table-of-contents/implement/changing-policies/overview/main (accessed on 11 August 2021).

37. Swapan, M.S.H.; Khan, S. From authoritarian transplantation to prescriptive imposition of good governance: Tracing the diffusion of western planning concepts in Bangladesh. Int. Plan. Stud. 2018, 23, 340-354. [CrossRef]

38. Saudi Vision 2030. “The Housing Vision Realization Program”. 2021. Available online: www.vision2030.gov.sa/en/programs/ Housing (accessed on 11 August 2021).

39. Vision Realization Office. Initiatives Related to the Saudi Vision 2030 Realization Programs. 2021. Available online: www.housing. gov.sa/en/node/1949 (accessed on 29 August 2021).

40. Saudi Vision 2030. The Housing Program Delivery Plan (2021-2025). 2020. Available online: https://www.vision2030.gov.sa/ media/ek5al1pw/housing_eng.pdf (accessed on 22 November 2021).

41. K1lınç, K.; Gharipour, M. Social Housing in the Middle East: Architecture, Urban Development, and Transnational Modernity; Indiana University Press: Bloomington, IN, USA, 2019.

42. Shiha, A.; Hariqi, F.; Slagur, J. Estimating the Number, Area and Type of Housing in the Kingdom of Saudi Arabia for the Next Twenty Years; King Abdulaziz City for Science and Technology: Riyadh, Saudi Arabia, 2005.

43. Elasrag, H. Affordable Housing in GCC Countries. 2016. Available online: https://papers.ssrn.com/sol3/papers.cfm?abstract_ $\mathrm{id}=2711977$ (accessed on 29 August 2021). [CrossRef]

44. Choi, C.G.; Lee, S.; Kim, H.; Seong, E.Y. Critical junctures and path dependence in urban planning and housing policy: A review of greenbelts and New Towns in Korea's Seoul metropolitan area. Land Use Policy 2019, 80, 195-204. [CrossRef]

45. Capoccia, G.; Kelemen, R.D. The Study of Critical Junctures: Theory, Narrative, and Counterfactuals in Historical Institutionalism. World Politics 2007, 59, 341-369. [CrossRef]

46. Hogan, J. The Critical Juncture Concept's Evolving Capacity to Explain Policy Change. Eur. Policy Anal. 2019, 5, 170-189. [CrossRef]

47. Bengtsson, B.; Ruonavaara, H. Comparative Process Tracing in Housing Studies. Int. J. Hous. Policy 2011, 11, 395-414. [CrossRef]

48. Jacobs, K.; Manzi, T. 'The party's over': Critical junctures, crises and the politics of housing policy. Hous. Stud. 2017, 32, 17-34. [CrossRef]

49. Collier, R.B.; Collier, D. Shaping the Political Arena: Critical Junctures, the Labour Movement and Regime Dynamics in Latin America; Princeton University Press: Princeton, NJ, USA, 1991.

50. Mahoney, J. Path dependence in historical sociology. Theory Soc. 2000, 29, 507-548. [CrossRef]

51. Setterfield, M. Path Dependency. In SSRN 2663719. 2015. Available online: https:/ / papers.ssrn.com/sol3/papers.cfm?abstract_ id=2663719 (accessed on 29 August 2021).

52. Capoccia, G. Critical junctures and institutional change. Adv. Comp.-Hist. Anal. 2015, 147-179. [CrossRef]

53. Lipset, S.M.; Rokkan, S. Cleavage Structures, Party Systems and Voter Alignments: An Introduction; Free Press: New York, NY, USA, 1967.

54. Von Schoultz, Å. Party Systems and Voter Alignments. In The Sage Handbook of Electoral Behaviour; SAGE: Los Angeles, CA, USA, 2017; pp. 30-55.

55. Johnson, D.A.; Schaffer, D. Learning from the Past-The History of Planning: Introduction. J. Am. Plan. Assoc. 1985, 51, 131-133. [CrossRef]

56. Mahoney, J. Analyzing Path Dependence: Lessons from the Social Sciences, in Understanding Change; Palgrave Macmillan: London, UK, 2006; pp. 129-139.

57. David, P.A. Clio and the Economics of QWERTY. Am. Econ. Rev. 1985, 75, 332-337.

58. Poku-Boansi, M. Path dependency in transport: A historical analysis of transport service delivery in Ghana. Case Stud. Transp. Policy 2020, 8, 1137-1147. [CrossRef]

59. Norris, M. Path Dependence and Critical Junctures in Irish Rental Policy: From Dualist to Unitary Rental Markets? Hous. Stud. 2014, 29, 616-637. [CrossRef]

60. Dear, M.J. Postmodernism and Planning. Environ. Plan. D Soc. Space 1986, 4, 367-384. [CrossRef]

61. Randolph, B.; Judd, B. A Framework for Evaluating Neighbourhood Renewal_Lessons Learned from New South Wales and South Australia; National Housing Conference: Brisbane, Australia, 2001. 
62. Al Nasiri, N.K.M. Planning, Policy and Performance: An Evaluation of the Effectiveness of the Social Housing Policy of Oman. Ph.D. Thesis, The University of Queensland, Brisbane, Australia, 2016.

63. Smith, D. Housing Markets and Policy Design in the Gulf Region: Overture, in Housing Markets and Policy Design in the Gulf Region; Gulf Research Centre Cambridge: Cambridge, UK, 2014.

64. Freeman, A. Housing Affordability-A Key to Social Cohesion in the Arabian Gulf, in Housing Markets and Policy Design in the Gulf Region; Gulf Research Centre Cambridge: Cambridge, UK, 2014.

65. Ministry of Economy \& Planning. All Development Plans. 2010. Available online: https://mep.gov.sa/en/development-plans (accessed on 17 September 2021).

66. Al-Hathloul, S.; Edadan, N. Evolution of settlement pattern in Saudi Arabia: A historical analysis. Habitat Int. 1993, 17, 31-46. [CrossRef]

67. Abu-Ghazzeh, T.M. The art of architectural decoration in the traditional houses of Al-Alkhalaf, Saudi Arabia. J. Archit. Plan. Res. 2001, 18, 156-177.

68. Al-Mayouf, A. Provision of public housing in Saudi Arabia: Past, current and future trends. Population 2011, $2004,2007$.

69. Wheeler, K. MODA, Ministries \& Other New Riyadh Buildings-Feb.-Jun. 1961. Wheeler, Keith Website: Keith's Old Military Photos. 2005. Available online: http:/ / www.wheelerfolk.org/military/album_index.htm (accessed on 17 September 2021).

70. Mubarak, F.A. Cultural Adaptation to Housing Needs: A Case Study. In IAHS Conference Proceedings; Citeseer: Riyadh, Saudi Arabia, 1999.

71. Al-Naim, M. Identity in transitional context: Open-ended local architecture in Saudi Arabia. Int. J. Archit. Res. Archit. Res. 2008, 2, 125-146.

72. Alkadi, A.H. Affordable Housing Standards for Low-Income Communities in Saudi Arabia; King Faisal University: Hofuf, Saudi Arabia, 2005; p. 15.

73. Sohail, M.S. Economic Diversification in Saudi Arabia: The Need for Improving Competitiveness for Sustainable Development. In The GCC Economies; Springer Science and Business Media LLC: Berlin/Heidelberg, Germany, 2012; pp. 147-156.

74. Alqahtany, A.; Mohanna, A.B. Housing challenges in Saudi Arabia: The shortage of suitable housing units for various socioeconomic segments of Saudi society. Hous. Care Support 2019, 22, 162-178. [CrossRef]

75. Ministry of Economy and Planning. Third Development Plan, Progress During the Second Plan; 1981. Available online: https: //www.mep.gov.sa/en/MediaCenter/Pages/DocumentsDetails.aspx?FId=11f492f8-7112-401d-a400-058ed406c0d1 (accessed on 2 September 2021).

76. Alhowaish, A.K. Eighty years of urban growth and socioeconomic trends in Dammam Metropolitan Area, Saudi Arabia. Habitat Int. 2015, 50, 90-98. [CrossRef]

77. Bureau of Experts at the Council of Ministers. Rules, Regulations and Policies. In Basic Law of Governance 2020.. Available online: https:/ /laws.boe.gov.sa/BoeLaws/Laws/LawDetails/16b97fcb-4833-4f66-8531-a9a700f161b6/1 (accessed on 7 September 2021).

78. Alasmari, F. An Institutional Analysis of State-Market Relations in the Saudi Arabian Housing System: A Case Study of Riyadh. Ph.D. Thesis, The University of Sydney, Sydney, Australia, 2018.

79. Alqahtany, A. Developing consensus-based measures for housing delivery in Dammam metropolitan area, Saudi Arabia. Int. J Hous. Mark. Anal. 2019, 2019. 12, 226-245. [CrossRef]

80. Ministry of Economy \& Planning. Sixth Development Plan, Regional and Urban Development 1999. Available online: https: / / www.mep.gov.sa/en/MediaCenter/Pages/DocumentsDetails.aspx?FId=341efc86-b012-4729-858f-66d4fd2bb984 (accessed on 10 September 2021).

81. Bahammam, A. Housing Development: The Homeless Hope, 1st ed.; Research and Information Center, King Saud University: Riyadh, Saudi Arabia, 2008

82. Ministry of Economy \& Planning. The Eighth Development Plan, Directions of the Eighth Development Plan. 2005. Available online: https: / / www.mep.gov.sa/en/MediaCenter/Pages/DocumentsDetails.aspx?FId=59f4fd61-ff5f-490c-a503-cb84fb7c0830 (accessed on 12 September 2021).

83. Ministry of Economy and Planning. Ninth Development Plan, Housing. 2010. Available online: https://www.mep.gov.sa/en/ MediaCenter/Pages/DocumentsDetails.aspx?FId=ccf45bb6-b5f5-45d5-b0f9-6aab8546f85e (accessed on 15 September 2021).

84. United Nations. Social Housing in the Arab Region: An Overview of Policies for Low-Income Households' Access to Adequate Housing; United Nations: Beirut, Lebanon, 2017.

85. Apostolos, K.; Balasis, E.; Patsavos, N. Social Housing as a State-Funded Mega Project: A Case Study from Saudi Arabia. Archit. Media Politics Soc. 2018, 13, 1-16. [CrossRef]

86. Bahammam, A. An approach to provide adequate housing in Saudi Arabia. J. Archit. Plan. 2018, 30, 55-78.

87. Alhubashi, H.H.M. Housing Sector in Saudi Arabia: Preferences and Aspirations of Saudi Citizens in the Main Regions; UPCommons. Portal del Coneixement Obert de la UPC: Catalunya, Spain, 2018.

88. Ministry of Housing. Developmental Housing." Programs and Initiatives and Partnership with the Private Sector. 2019. Available online: https:/ / www.housing.gov.sa/en (accessed on 15 September 2021).

89. Albassam, B.A. Economic diversification in Saudi Arabia: Myth or reality? Resour. Policy 2015, 44, 112-117. [CrossRef]

90. Bahammam, A. The Difficulty of Obtaining and Possessing a Dwelling in Light of the Recent Circumstances in Saudi Arabia. Soc. J. 2015, 9, 10-23. 
91. Mohanna, A.B.; Alqahtany, A. Identifying the preference of buyers of single-family homes in Dammam, Saudi Arabia. Int. J. Hous. Mark. Anal. 2019, 13, 165-184. [CrossRef]

92. Alshuwaikhat, H.M.; Mohammed, I. Sustainability Matters in National Development Visions-Evidence from Saudi Arabia's Vision for 2030. Sustainability 2017, 9, 408. [CrossRef]

93. Salam, A.A.; Elsegaey, I.; Khraif, R.; Al-Mutairi, A. Population distribution and household conditions in Saudi Arabia: Reflections from the 2010 Census. SpringerPlus 2014, 3, 530. [CrossRef] [PubMed]

94. General Authority for Statistics in Saudi Arabia. Demography Survey; General Authority for Statistics: Riyadh, Saudi Arabia, 2016. 